\title{
Foreign Direct Investment and Economic Growth in Cote D'Ivoire: A Time Series Analysis
}

\author{
Kyle A. Johnston \\ Department of Economics, Trinity College, Hartford, CT, 06106 \\ E-mail: Kyle.johnston@trincoll.edu \\ Miguel D. Ramirez \\ Department of Economics, Trinity College, Hartford, CT, 06106 \\ E-mail: Miguel.ramirez@trincoll.edu
}

Received: May 21, 2015 Accepted: June 9, 2015

doi:10.5296/ber.v5i2.7638

URL: http://dx.doi.org/10.5296/ber.v5i2.7638

\begin{abstract}
This paper investigates the impact of foreign direct investment (FDI) inflows on economic growth in Cote D'Ivoire during the 1975-2011 period. The selection of this African nation is motivated by the rapid inflows it has experienced over the past decade. Using unit root and cointegration analysis, the resulting error correction model (ECM) suggests that gross fixed capital formation (GFCF) has a short-run positive impact on economic growth, while FDI, the repatriation of net income abroad, and periods involving structural breaks, have a negative effect on economic growth in Cote D'Ivoire. In addition, the negative error correction term indicates that deviations from long-run per capita growth during the current year are corrected relatively quickly in the following year, ceteris paribus. The unexpected negative effect of FDI on economic growth may be due to the significant repatriation of profits and dividends the country has experienced in recent years.
\end{abstract}

JEL: C22, F21, O52

Keywords: Foreign direct investment, Gross fixed capital formation, Net income from abroad 


\section{Introduction}

Over the past two decades, the world economy has become increasingly open. As a result, flows of foreign direct investment (FDI) into developing countries have grown substantially (see De Mello, Jr., 1997; Elmawazini, 2014; Ramirez and Komuves, 2014; and Ram and Zhang, 2002). It is widely held that a country's overall investment position is tied to its economic growth as the development path of FDI exhibits a dynamic relationship with the development level of the corresponding economy (see Dunning 1981, 1988). FDI inflows are considered to provide the capital necessary for spurring economic growth, as well as technological and other production spillovers to the recipient country that can increase economic efficiency (see Ramirez, 2006; and Kumar, 2007). As a result, multi-national enterprises (MNEs) may be the most efficient vehicle spurring international production (Dunning 1981). Africa, in particular, has seen exponential growth in FDI flows into the continent since 2000 (UNCTAD 2014). With cheap labor and abundant natural resources, the continent provides locational and competitive advantages that draw in FDI from MNEs, two sets of advantages described in Dunning's eclectic paradigm (1981). One African country that has seen such growth in its FDI inflows is Cote D'Ivoire. As the world's leader in cocoa production its prospects for economic growth and development make the country an attractive destination for FDI flows.

Although FDI in Africa has increased in recent decades, there is still uncertainty surrounding Africa's ability to catch up to the world economy. The investment development path movements of a county are shaped by various factors such as the country's size, its level of development, and its access to natural resources (Dunning 1981). Africa continues to be marginal to the global economy, while the world economy remains crucial to Africa's own economic growth and development (Bigsten 2002). As a result, it is important to examine the impact of FDI on the growth prospects of the African economy. Ghana, Cote D'Ivoire's eastern neighbour and fellow cocoa producer, was recently the subject of an econometric analysis of FDI's impact on economic growth. Nkechi (2013) finds that FDI has a positive and significant effect on economic growth in Ghana in the long run. The African continent is abundant in natural resources, a characteristic that is often a main factor in attracting FDI. For instance, much of the FDI into Tanzania is resource-seeking in nature and directed towards the mining sector as the country is one of Africa's largest gold producers (Rutaihwa 2012). This fact questions how much FDI can benefit the country if it is mainly being directed towards a mining enclave with little forward and backward linkages to the rest of the economy (see Ram and Zhang, 2002). Similar to Tanzania, Cote D'Ivoire is an abundant producer of a natural resource and, thus, it will be interesting to examine the impact of FDI on this emerging economy. FDI is also essential for financing capital formation and promoting economic growth in emerging economies, and it is a source of financing that is considered to be relatively stable and involves a longer commitment than portfolio flows such as bond and equity investment. In this connection, Kanu (2014) finds that gross fixed capital formation (GFCF), which includes land improvements, plant/machinery purchases, and infrastructure development, has a positive and significant long-run relationship with economic growth in Nigeria (Kanu 2014). 
In light of the cited literature, this paper will examine the impact of gross fixed capital formation, FDI inflows, and net income from abroad on the GDP per capita of Cote D'Ivoire. Net income from abroad (NI_FA) will be included as a proxy variable to determine how much income generated as a result of FDI inflows remains in the recipient country or is eventually repatriated back to the parent company in the source country. Critics on the left argue that FDI inflows often give rise to substantial reverse flows in the form of remittances of profits and dividends that divert resources away from the financing of private capital formation (see Cypher and Dietz, 2004; and Ram and Zhang, 2002). Due to the fact that most macro variables are non-stationary over time, each of the variables in question will be tested for unit roots and a cointegration analysis will be performed. The estimated model will be an error correction model (ECM) that reconciles both the short and long-run behavior of the variables in the model (see Engle and Granger, 1987).

As is common with many macro variables, the logarithms of GDP per capita (LGDP_PC) and GFCF (LGFCF) will be taken; however, both FDI and net income from abroad contain negative values and it will not be possible to take the logarithms of these variables. The data for each of these variables were obtained from the World Bank Development Indicators. The power of the unit root tests is greatly reduced if the number of observations in question is fewer than 30. On the other hand, a longer time span improves the power of the tests as this allows for greater variability and tends to offset the relatively small number of observations (see Charemza et al., 1997). The time period that will be used in this study ranges from 1975 to 2011 , or 37 observations of yearly data. While drawing on 50 observations is ideal, examining 37 years of data is sufficient for time series analysis.

\section{Variables}

This study seeks to examine the impact of FDI and GFCF on economic growth in Cote D'Ivoire. As a result, GDP per capita will be used as the dependent variable. GDP per capita was chosen instead of GDP because it is standard practice in the literature to use it as an indirect measure of the standard of living in a country. Increases in GDP per capita over time tend to proxy for economic growth as well as potential increases in productivity. Drawing from the World Bank database, GDP per capita is measured in current US dollars. In addition, this variable was translated to a logarithmic form in order to account for the exponential growth that is common in GDP and thus make it easier to see how GDP per cap depends on its previous values.

FDI is the first "independent variable". The data for this variable were obtained from the World Bank and is measured in terms of FDI inflows into Cote D'Ivoire in current US dollars to keep it consistent with the measure for GDP per capita. Based on previous literature, such as the study that found a positive long-term relationship between economic growth and FDI in Ghana (Nkechi 2013), it is expected that FDI will positively affect GDP per capita. Due to the spillovers and financing for capital formation that FDI provides, it can be expected that FDI will help to spur economic growth and improve the standard of living in Cote D'Ivoire. However, there is a chance that FDI undermines economic growth in the long run if, on a net basis, the investment mainly provides the parent companies/countries with income rather than 
the recipient country, ceteris paribus.

A second "independent variable" to be used in the model is gross fixed capital formation (GFCF). The data for GFCF comes from the World Bank and is measured in current US dollars, consistent with the measures for the other variables. GFCF follows a similar growth pattern to GDP per capita and, just as in the case of GDP per capita, it was transformed into logarithmic form. Previous literature regarding GFCF, such as the analysis of GFCF and economic growth in Nigeria (Kanu 2014), suggests that GFCF has a positive long-run relationship on economic growth. In addition, GFCF involves improvements to infrastructure within a country, which provides the basis for further economic growth. For these reasons, it can be expected that GFCF will have a positive relationship with GDP per capita as GFCF can improve economic growth and, based on infrastructure improvements, also lead to an improvement in productivity.

A third independent variable within this model is net income from abroad (NI_FA). Net income from abroad can reveal if the income generated from gross FDI inflows remain in the recipient country or are remitted back to the parent company in the form of profits and dividends. The data for net income from abroad comes from the World Bank and is measured in terms of current US dollars. Net income from abroad is negative in each year from 1975 to 2011 for Cote D'Ivoire, suggesting that FDI may be diverting resources away from the country. Due to this, it is expected that GDP per capita and net income from abroad will have a negative relationship as net income from abroad may undermine economic growth and development.

\section{Results}

\subsection{Unit Root Tests and Correlograms}

Most macro time series tend to be non-stationary and integrated of order one. As a result, each of the variables in this model were tested for unit roots using the Augmented Dickey-Fuller, Phillips-Peron, Kwiatkowski-Phillips-Schmidt-Shin (confirmatory), and Zivot-Andrews tests. In addition, the Doldado-Sosvilla-Rivera (1990) procedure was used in the ADF, PP, and KPSS tests in order to find the correct specification (constant and/or trend) to run the tests, starting with the most general model that includes both a trend and a constant variable, moving to a model with only a constant if the trend is found to be insignificant, and subsequently moving to a model that includes neither variable if the intercept is then found to be insignificant. Table 1 below contains the specifications under which each unit root test was performed for each variable based on the DSR procedure. 
Table 1. Unit Root Tests Level Form

\begin{tabular}{|l|l|l|l|}
\hline \multicolumn{5}{|c|}{ ADF } \\
\hline Variable & Specification through DSR procedure & ADF 5\% Critical Value & ADF Stat \\
\hline LGDP_PC & Constant & -2.95 & -2.03 \\
\hline FDI & Trend and Constant & -3.54 & -2.87 \\
\hline LGFCF & Neither & -1.95 & 0.70 \\
\hline NI_FA & Constant & -2.95 & -2.04 \\
\hline \multicolumn{5}{|c|}{ PP } \\
\hline Variable & Specification through DSR procedure & PP 5\% Critical Value & PP Stat \\
\hline LGDP_PC & Constant & -2.95 & -2.37 \\
\hline FDI & Trend and Constant & -3.54 & -2.84 \\
\hline LGFCF & Neither & -1.95 & 0.66 \\
\hline NI_FA & Constant & -2.95 & -2.1 \\
\hline \multicolumn{5}{|c|}{ KPSS } \\
\hline Variable & Specification through DSR procedure & KPSS 5\% Critical Value & KPSS Stat \\
\hline LGDP_PC & Constant & 0.463 & 0.206 \\
\hline FDI & Trend and Constant & 0.146 & 0.107 \\
\hline LGFCF & Trend and Constant & 0.146 & 0.149 \\
\hline NI_FA & Trend and Constant & 0.146 & 0.135 \\
\hline \multicolumn{5}{|l|}{ ZA } & ZA 5\% Critical Value & ZA Stat \\
\hline Variable & Structural Break & -5.08 & -3.96 \\
\hline LGDP_PC & 2000 & -5.08 & -4.34 \\
\hline FDI & 1995 & -5.08 & -3.59 \\
\hline LGFCF & 1989 & -5.08 & -4.52 \\
\hline NI_FA & 1994 &
\end{tabular}

Ultimately, the tests on each of the variables indicated integration of order 1. Each of the tests tended to confirm the apparent presence of a unit root in level form, although the KPSS test, which holds a null hypothesis of stationarity, contradicted the other three tests for each of the variables except for LGFCF as the null hypothesis of stationarity failed to be rejected (see Table 1). However, as the other three tests, including the PP test which is most powerful, indicated the presence of a unit root, it appears that each of the variables contain a unit root in level form. Furthermore, the ZA test for unit roots under one structural break showed an apparent break in 2000 for LGDP_PC, 1995 for FDI, 1989 for LGFCF, and 1994 for NI_FA (see Table 1). Performing these tests on the first differenced forms of the series yielded results showing that each of the variables appears to be stationary, thus indicating integration of order 1 (see Table 2 below). 
Table 2. Unit Root Tests First Difference

\begin{tabular}{|l|l|l|l|}
\hline \multicolumn{5}{|c|}{ ADF } \\
\hline Variable & Specification through DSR procedure & ADF 5\% Critical Value & ADF Stat \\
\hline LGDP_PC & Constant & -2.95 & -4.56 \\
\hline FDI & Trend and Constant & -3.54 & -7.12 \\
\hline LGFCF & Neither & -1.95 & -4.92 \\
\hline NI_FA & Constant & -2.95 & -6.36 \\
\hline \multicolumn{5}{|c|}{ PP } & PP Stat \\
\hline Variable & Specification through DSR procedure & PP 5\% Critical Value & -4.55 \\
\hline LGDP_PC & Constant & -2.95 & -7.12 \\
\hline FDI & Trend and Constant & -3.54 & -4.92 \\
\hline LGFCF & Neither & -1.95 & -6.35 \\
\hline NI_FA & Constant & -2.95 & KPSS \\
\hline \multicolumn{5}{|l|}{} & 0.463 & 0.11 \\
\hline Variable & Specification through DSR procedure & KPSS 5\% Critical Value & KPSS Stat \\
\hline LGDP_PC & Constant & 0.146 & 0.05 \\
\hline FDI & Trend and Constant & 0.146 & 0.08 \\
\hline LGFCF & Trend and Constant & 0.146 & 0.08 \\
\hline NI_FA & Trend and Constant & \multicolumn{2}{|l|}{} \\
\hline
\end{tabular}

Another popular method for checking stationarity in a series is through looking at the correlogram of the series. If the series are non-stationary in level form, the autocorrelation function $(\mathrm{ACF})$ for the correlogram of the series should not die down quickly and may show patterns. In each of the correlograms of the series for this model, the ACF's do not seem to show signs of quick decay and in some instances show clear patterns, as in the case of net income from abroad (see Figures 1-4). As a result, the correlograms seem to be consistent with the findings of the unit root tests, signifying that the series are non-stationary.

\begin{tabular}{|c|c|c|c|}
\hline \multicolumn{2}{|c|}{ Autocorrelation } & \multicolumn{2}{|c|}{ Partial Correlation } \\
\hline 1 & $\square$ & 1 & $\square$ \\
\hline 1 & $\square$ & $1 \square$ & 1 \\
\hline & 1 & 14 & 1 \\
\hline 1 C & 1 & 1 든 & 1 \\
\hline 1 든 & 1 & 1 & 1 \\
\hline 1 C & 1 & 10 & 1 \\
\hline 10 & 1 & 1 믄 & 1 \\
\hline 10 & 1 & 1 & 1 \\
\hline 10 & 1 & 1 & 1 \\
\hline 10 & 1 & 11 & 1 \\
\hline 10 & 1 & 10 & 1 \\
\hline 10 & 1 & 1 & 1 \\
\hline 1 든 & 1 & 1 믄 & 1 \\
\hline 1ם & 1 & 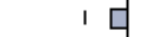 & 1 \\
\hline 1 등 & 1 & 10 & 1 \\
\hline 1 C & 1 & 1 & 1 \\
\hline
\end{tabular}

Figure 1: LGDP_PC Correlogram

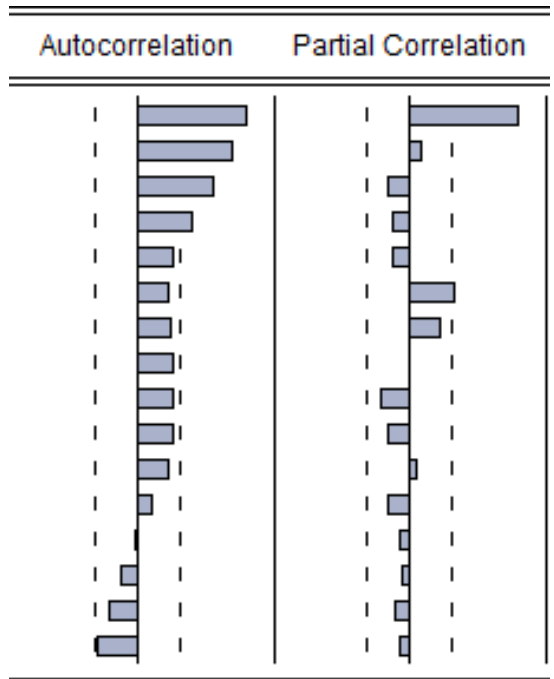

Figure 2: FDI Correlogram 


\begin{tabular}{|c|c|c|c|c|c|c|c|}
\hline \multicolumn{2}{|c|}{ Autocorrelation } & \multicolumn{2}{|c|}{ Partial Correlation } & \multicolumn{2}{|c|}{ Autocorrelation } & \multicolumn{2}{|c|}{ Partial Correlation } \\
\hline 1 & E & 1 & $\bar{E}$ & 1 & & I & 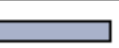 \\
\hline 1 & 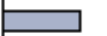 & $\square$ & 1 & 1 & $\square$ & 1 & $\mathrm{I}$ \\
\hline 1 & $\square$ & 1 다 & 1 & 1 & $\square$ & 1 다 & 1 \\
\hline 1 & 21 & 10 & 1 & 1 & $\square$ & $\mathrm{\square}$ & 1 \\
\hline 1 & 1 & 15 & ] 1 & 1 & ] 1 & 1 & 1 \\
\hline 1 & 1 & 1 & 1 & 1 & 1 & 1 & 曰 1 \\
\hline 1 & 1 & 1 든 & 1 & 10 & 1 & 1 С & 1 \\
\hline 1 & 1 & 10 & 1 & 1 미 & 1 & 1 다 & 1 \\
\hline 1 & 1 & 1 & 1 & 1 口 & 1 & 10 & 1 \\
\hline 1 & 1 & 14 & 1 & I & 1 & 15 & 1 \\
\hline 15 & 1 & 14 & 1 & $\square$ & I & 1 다 & I \\
\hline 1[ & 1 & 10 & ] 1 & $\square$ & 1 & 1 С & 1 \\
\hline 1[ & 1 & 1 & 1 & $\square$ & 1 & 1 & 1 \\
\hline 1[ & 1 & 1 & 1 & $\square$ & 1 & 1 & 1 \\
\hline 15 & 1 & 1 & 1 & $\square$ & 1 & I & $\sqsupset$ । \\
\hline 15 & 1 & 1 प & 1 & $1 \square$ & 1 & 1 & 口 \\
\hline
\end{tabular}

Figure 3: LGFCF Correlogram Figure 4: NI_FA Correlogram

\subsection{Cointegration Analysis}

It is possible that a linear combination of two non-stationary series results in a stationary process. In such a case, the series are cointegrated and contain a long-run relationship. Due to the fact that each of the variables in question are seemingly non-stationary and that there are more than two variables, it is possible that multiple cointegrating relationships exist. As a result, the Johansen approach must be used to test for cointegration. In order to test for cointegration, an appropriate lag length must be set, with the most appropriate length as the one which minimizes the Schwarz criterion (SBC), a criterion which penalizes the addition of parameters. Since this is yearly data, 1 or 2 lags should be sufficient. Using a VAR model, first with 2 lags and then with 1 lag, it is determined that 1 lag is the optimal length as it generates the lowest SBC.

Given that the optimal lag length has been determined, the Pantula Principle is utilized in order to determine which of the five possible models is the proper model through which to test for cointegration (see Pantula, 1989). Since models 1 and 5 are unlikely to happen, models 2, 3, and 4 are tested. Model 4 is the first model at which the null hypothesis of no cointegration fails to be rejected using the trace statistics and, thus, model 3 is selected as the correct model using the Pantula Principle (see Table 3). Then, through examining model 3, it is determined that one cointegrating vector is present (see Table 4). Furthermore, the normalized cointegrating coefficients (normalizing reverses the sign) under one cointegrating equation display the expected signs except for FDI, although, as previously discussed, there is a potential for FDI to have a negative impact on GDP_PC (see Table 5). 
Table 3. Johansen Approach/ Pantula Principle

\begin{tabular}{|l|l|l|l|l|l|l|}
\hline & \multicolumn{3}{|c|}{ Trace Test } & \multicolumn{3}{c|}{ Maximum Eigenvalue Test } \\
\hline $\mathrm{R}$ & Model 2 & Model 3 & Model 4 & Model 2 & Model 3 & Model 4 \\
\hline 0 & $54.88(54.08)^{*}$ & $52.15(47.85)^{*}$ & $60.97(63.88)$ & $31.38(28.59)^{*}$ & $31.01(27.58)^{*}$ & $31.87(32.12)$ \\
\hline 1 & $23.5(35.19)$ & $21.14(29.8)$ & $29.11(42.92)$ & $14.65(22.3)$ & $14.65(21.13)$ & $15.38(25.82)$ \\
\hline 2 & $8.85(20.26)$ & $6.49(15.49)$ & $13.73(25.87)$ & $5.15(15.89)$ & $4.41(14.26)$ & $9.84(19.39)$ \\
\hline 3 & $3.7(9.16)$ & $2.08(3.84)$ & $3.89(12.52)$ & $3.7(9.16)$ & $2.08(3.84)$ & $3.89(12.52)$ \\
\hline
\end{tabular}

*Denotes rejection of null hypothesis at $5 \%$ level, critical value in parentheses

Table 4. Model 3 Results

\begin{tabular}{|l|l|l|l|l|}
\hline \multicolumn{5}{|l|}{ Unrestricted Cointegration Rank Test } \\
\hline Hypothesized No. of CE(s) & Eigenvalue & Trace Statistic & 0.05 Critical Value & Prob.** \\
\hline None & 0.587668 & 52.1512 & 47.85613 & 0.0187 \\
\hline At most 1 & 0.342096 & 21.14378 & 29.79707 & 0.3487 \\
\hline At most 2 & 0.118442 & 6.489399 & 15.49471 & 0.6376 \\
\hline At most 3 & 0.057620 & 2.07715 & 3.841466 & 0.1495 \\
\hline Trace Test indicates 1 cointegrating equation(s) at the 0.05 level \\
\hline * Denotes rejection of the hypothesis at the 0.05 level \\
\hline **MacKinnon-Haug-Michelis (1999( p-values \\
\hline
\end{tabular}

Table 5. Normalized Cointegrating Coefficients with 1 Cointegrating Equation

\begin{tabular}{|l|l|l|l|}
\hline \multicolumn{4}{|l|}{ Cointegrating equation: Log Likelihood $=-1334.552$} \\
\hline Normalized Cointegrating Coefficients (Standard Error in parenthesis) \\
\hline LGDP_PC & LGFCF & FDI & NI_FA \\
\hline 1.00000 & -.558626 & $5.94 \mathrm{E}-10$ & $3.18 \mathrm{E}-10$ \\
\hline & $(0.03951)$ & $(9.9 \mathrm{E}-11)$ & $(3.9 \mathrm{E}-11)$ \\
\hline
\end{tabular}

\subsection{Error-Correction Model}

After determining that a unique cointegrating vector is present, an error correction model was created with the variables in differenced form. In addition, a dummy variable was added to take into account each of the structural breaks of 1989, 1994, 1995, and 2000. These structural breaks occur during the end of the Cold War with the fall of the Berlin Wall in 1989, economic expansion across many developed countries during 1994-1995, and the post-Asian crisis in 1998 signifying macro factors that could very well effect economic growth in developing countries. The model reports an adjusted $\mathrm{R}^{2}$ of .674 (See Figure 5), meaning that $67.4 \%$ of the variance in LGDP_PC can be explained by the variance in the explanatory variables. This is a relatively high statistic and signifies strong explanatory power in the model. The AIC and SBC stats of -2.21 and -1.94 (Figure 5), respectively, are low which is ideal as the addition of nonsense variables is penalized by raising these measures. In addition, the F-stat of 15.44 results in a p-value of practically 0 (Figure 5), signifying an overall goodness of fit that is quite strong. 


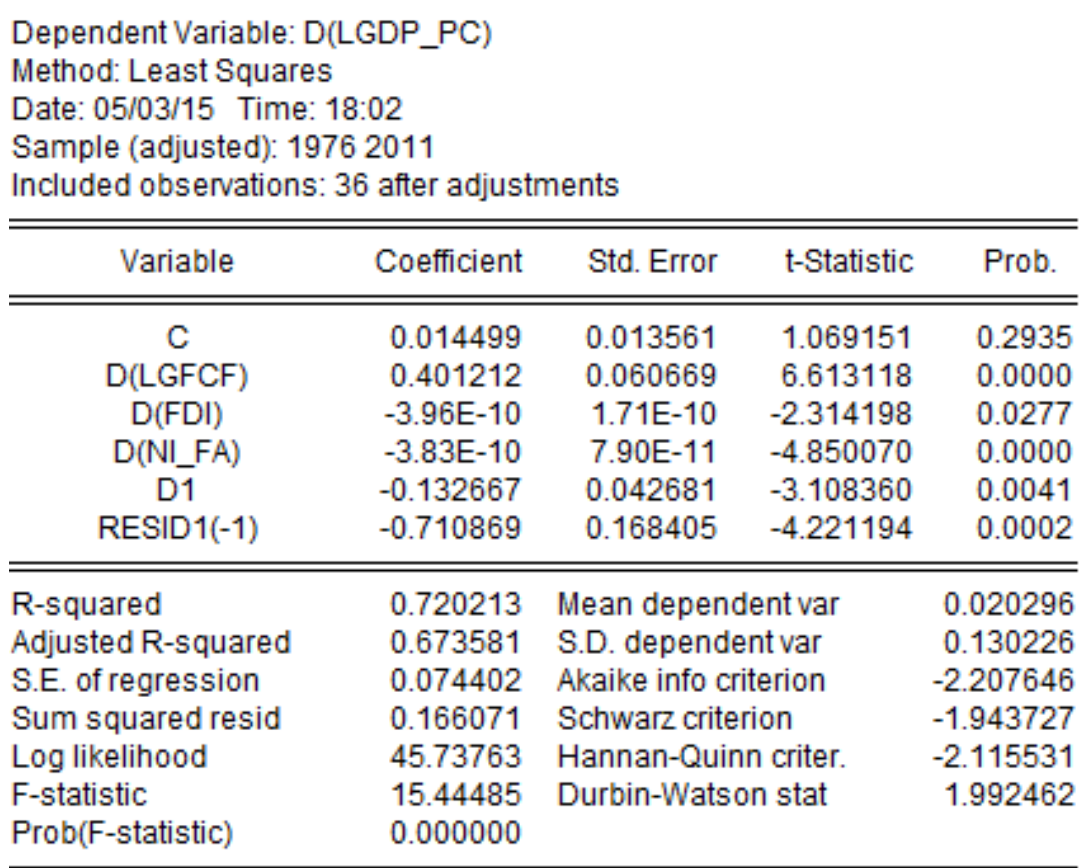

Figure 5. Results of Error Correction Model Estimation

Each of the variables included is significant based on the t-statistics, with all variables except for LGFCF having negative relationships with LGDP_PC. A $10 \%$ increase in gross fixed capital formation implies a $4.01 \%$ increase in GDP per capita, holding all other independent variables constant. This suggests that GFCF does in fact have a positive effect on economic growth in the long run. A $\$ 100$ million increase in FDI implies a 3.96\% decrease in GDP per capita in Cote D'Ivoire based on the log-linear relationship. The negative coefficient suggests that FDI does indeed undermine economic growth which may be due to the repatriation of income out of Cote D'Ivoire. A $\$ 100$ million increase in net income from abroad implies a $3.83 \%$ decrease in GDP per capita in Cote D'Ivoire. This coefficient displays the fact that resources are being diverted away from the country, the result of which is a negative effect on economic growth. The coefficient of -0.133 on D1 implies that during the structural break years of important economic events, GDP per capita in Cote D'Ivoire is $13.3 \%$ lower than in years outside of important macro economic times. These years may have contributed to changes in the global economy that favored FDI and, based on this model, negatively impacted GDP per capita in Cote D'Ivoire or macro factors that hurt the global economy as a whole. Lastly, based on the error correction term coefficient, a $10 \%$ deviation from the long run equilibrium GDP per capita level results in a $7.1 \%$ shift back towards equilibrium in the following period. The coefficient on this term is negative and significant suggesting that there does indeed exist a long-run equilibrium within the model.

This ECM model can also be used for forecasting purposes. One measure of a forecast's quality is the Theil Inequality Coefficient. After generating a forecast, the resulting TIC is .282 which is encouraging as the optimal level suggested by Theil (1966) is below 0.3. As a result, this model appears to be an efficient tool for forecasting purposes (See Figure 6). 


\section{MlMacrothink}

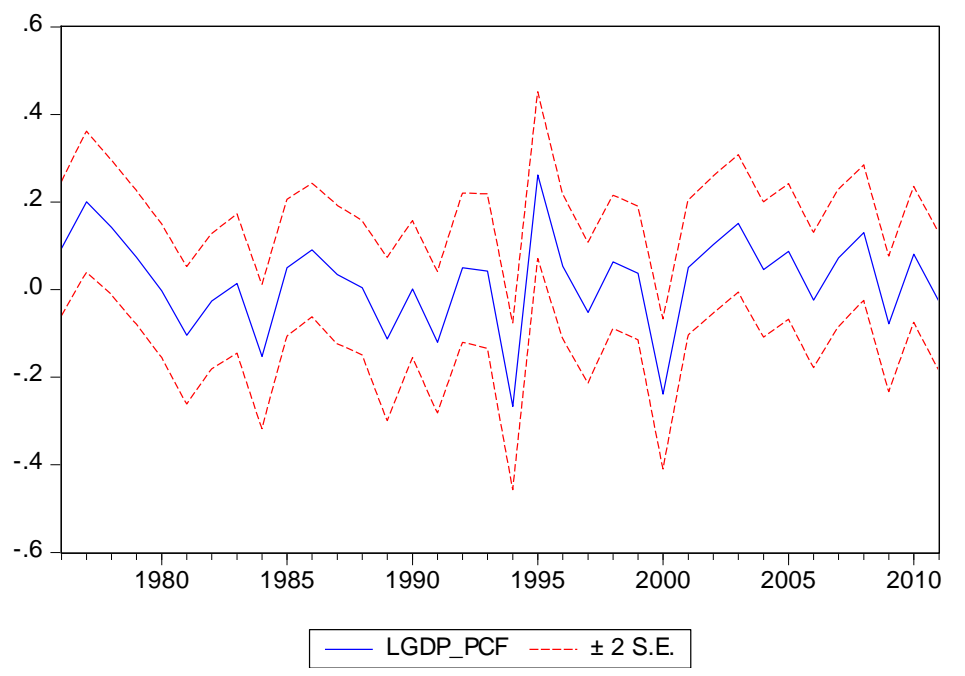

Business and Economic Research

ISSN 2162-4860

2015, Vol. 5, No. 2

Figure 6. In-Sample Forecast

\section{Problems with the Model}

Serial correlation and multicollinearity are two problems that could arise in this model and affect the efficiency of the results. To test for these, the Breusch-Godfrey LM test will be used for serial correlation and the Variance Inflation Factors will be calculated for multicollinearity. Testing for serial correlation with 2 lags results in an F-statistic that fails to reject the null hypothesis of no serial correlation and the model does not appear to suffer from this problem (see Table 6). In addition, none of the Variance Inflation Factors of the coefficients is at or above 5, and thus it appears as though multicollinearity is not a problem either (see Table 7).

Table 6. B-G Test (2 lags)

\begin{tabular}{|l|l|l|l|}
\hline \multicolumn{4}{|l|}{ Breusch-Godfrey Serial Correlation LM Test } \\
\hline F-Statistic & 0.401226 & Prob. F(2,28) & 0.6733 \\
\hline Obs*R-squared & 1.002979 & Prob. Chi-Square(2) & 0.6056 \\
\hline
\end{tabular}

Table 7. Variance Inflation Factors

\begin{tabular}{|l|l|l|l|}
\hline Variable & Coefficient Variance & Uncentered VIF & Centered VIF \\
\hline C & 0.000184 & 1.195995 & NA \\
\hline D(LGFCF) & 0.003681 & 1.494192 & 1.471371 \\
\hline D(FDI) & $2.93 \mathrm{E}-20$ & 1.461606 & 1.450481 \\
\hline D(FI_NA) & $6.24 \mathrm{E}-21$ & 1.068189 & 1.042936 \\
\hline D1 & 0.001822 & 1.316275 & 1.170022 \\
\hline RESID1(-1) & 0.028360 & 1.486070 & 1.485114 \\
\hline
\end{tabular}

In time-series analysis, the variances of the errors may vary over time and there may be autocorrelation in the variances. To test for this, an Engle Arch(1) test is performed. Based on the results, the null hypothesis of no autocorrelation in the variances of the residuals can be rejected and it appears that the variances of the error terms suffer from autocorrelation (see 
Table 8). Lastly, based on the Ramsey Reset Test F-stat of 1.15 and corresponding p-value of .29, it appears that the model is correctly specified as the null hypothesis of correct specification fails to be rejected (see Table 9).

Table 8. Engle Arch(1) Test

\begin{tabular}{|l|l|}
\hline \multicolumn{2}{|l|}{ Heteroscedasticity Test: ARCH } \\
\hline F-Statistic & 8.277129 \\
\hline Prob. F(1,33) & 0.0070 \\
\hline Obs*R-Squared & 7.018403 \\
\hline Prob. Chi-Square(1) & 0.0081 \\
\hline
\end{tabular}

Table 9. Ramsey Reset Test

\begin{tabular}{|l|l|l|l|}
\hline & Value & DF & Prob \\
\hline t-statistic & 1.073732 & 29 & 0.2918 \\
\hline F-statistic & 1.152901 & $(1,29)$ & 0.2918 \\
\hline Likelihood Ratio & 1.403471 & 1 & 0.2361 \\
\hline
\end{tabular}

Equation: ECM1

Specification: D(LGDP_PC) C D(LGFCF) D(FDI) D(NI_FA) D1 RESID1(-1)

Omitted Variables: Squares of fitted values

\section{Conclusion}

This paper established that each of the variables in the simple growth model were found to be integrated of order one and, more importantly, it was determined that one cointegrating relationship exists among the variables that keeps them in proportion to one another over time. The resulting ECM suggests that GFCF has a short-run positive impact on economic growth, while FDI, net income from abroad, and the periods involving the structural breaks have a negative effect on economic growth in Cote D'Ivoire. In addition, the negative error correction term indicates that a deviation from long-run per capita growth during the current year is corrected relatively quickly in the following year, ceteris paribus. The negative impact of FDI found in this study contradicts the findings in the analysis performed on Ghana that found a positive long-run relationship (Nkechi 2013). The findings of this analysis suggest that, as it stands, FDI is not a significant driver of economic growth in Cote D'Ivoire, which may be due, in part, to the significant repatriation of net income out of the country. It appears as though Cote D'Ivoire may be in the second stage of the investment development path outlined by Dunning and Narula (1996), in which a country may benefit from establishing policies and/or institutions related to FDI that prevent resources from being diverted away from capital formation and economic growth (e.g., a minimum stay requirement for FDI and/or restrictions on the repatriation of profits and dividends); this is in accordance with Dunning's (1981) theory that a nation's government policies play a key role in the subsequent consequences arising from FDI inflows. Cote D'Ivoire may be in the second stage of the investment development path outlined by Dunning and Narula (1996), in which a country experiences a lack of outward investment, but an increase of inward investment. While this 
study covers over 30 years, an expanded number of observations may result in more conclusive results.

\section{References}

Bigsten, A. (2002). Can Afica Catch Up? World Economic Journal, 3(2), 17-33.

Charemza, W. W., \& Deadman, D. F. (1997). New Directions in Econometric Practice: General to Specific Modelling, Cointegration and Vector Autoregression. U.K.: Edward Elgar Publishers.

Cypher, J. M., \& Dietz, J. L. (2004). The Process of Economic Development. New York: Routledge.

De Melllo, Luiz R., Jr. (1997). Foreign Direct Investment in Developing Countries and Growth: A Selective Survey. The Journal of Development Studies, 34(1), 1-34. http://dx.doi.org/10.1080/00220389708422501

Doldado, J., Jenkinson, T., and Sosvilla-Rivero S. (1990). Cointegration and Unit Roots, $\begin{array}{lllll}\text { Journal of } & \text { Economic } & \text { Surveys, } & 4, & \text { 249-73. }\end{array}$ http://dx.doi.org/10.1111/j.1467-6419.1990.tb00088.x

Dunning, J. H. (1981). International Production and the Multinational Enterprise. London: Allen \& Unwin.

Dunning, J. H. (1988). The Eclectic Paradigm of International Production: A Restatement of Some Possible Extensions, Journal of International Business Studies, 19(1), 1-31. http://dx.doi.org/10.1057/palgrave.jibs.8490372

Dunning, J. H., \& R. Narula (1996). The Investment Development Path Revisited: Some Emerging Issues, in Foreign Direct Investment and Governments (Eds.) J. H. Dunning and R. Narula, Routledge, London, pp.1--41.

Elmawazini, K. (2014). FDI Spillovers, Efficiency Change and Host Country Labor Productivity: Evidence from GCC Countries. Atlantic Economic Journal, 42(4), 399-411. http://dx.doi.org/10.1007/s11293-014-9428-0

Engle, R. F., \& Granger, C.W.J. (1987). Cointegration and Error Correction: Representation, Estimation, and Testing. Econometrica, 55, 252-276. http://dx.doi.org/10.2307/1913236

Kanu, S. I., \& Ozurumba, B. A. (2014). Capital Formation and Economic Growth in Nigeria. Global Journal of Human-Social Science: E Economics, 4(14), 43-58.

Kumar, A. (2007). Does Foreign Direct Investment help Emerging Economies? Economic Letters, 2(1), 1-8.

Nkechi, O. A. (2013). An Econometric Analysis of the Impact of Foreign Direct Investment on Economic Growth in Ghana: The Role of Human Capital. International Journal of Humanities and Social Science Innovation, 2(8), 12-20.

Pantula, S. G. (1989). Testing for Unit roots in Time Series Data. Economic Theory, 5, 
256-271. http://dx.doi.org/10.1017/S0266466600012421

Ram, R., \& Zhang, K.H. (2002). Foreign Direct Investment and Economic Growth: Evidence from Cross-Country Data for the 1990s. Economic Development and Cultural Change, 51, 205-215. http://dx.doi.org/10.1086/345453

Ramirez, M. D., \& Komuves, Z. (2014). Economic Infrastructure, Private Capital Formation, and FDI Inflows to Hungary: A Unit Root and Cointegration Analysis With Structural Breaks. Atlantic Economic Journal, 42(4), 367-382. http://dx.doi.org/10.1007/s11293-014-9436-0

Ramirez, M. D. (2006). Is Foreign Direct Investment Beneficial for Mexico? An Empirical Analysis. World Development, 34, 802-817. http://dx.doi.org/10.1016/j.worlddev.2006.01.001

Rutaihwa, J., \& Simwela, A. (2012). Econometric Analysis of FDI in the Mining Sector to Tanzania's Export Capacity. International Journal of Academic Research in Business and Social Sciences, 2(10), 174-191.

Theil, H. (1966). Applied Economic Forecasting. Amsterdam: North-Holland.

UNCTAD (2014). Inward and Outward Foreign Direct Investment Flows, Annual, 1970-2013: http://unctadstat.unctad.org/wds/TableViewer/chartView.aspx

World Bank (2014). World Bank African Development Indicators: http://data.worldbank.org/country/cote-divoire

\section{Copyright Disclaimer}

Copyright for this article is retained by the author(s), with first publication rights granted to the journal.

This is an open-access article distributed under the terms and conditions of the Creative Commons Attribution license (http://creativecommons.org/licenses/by/3.0/). 